Д-р техн. наук Т.В. Бутько, Д.О. Григоренко

\title{
ФОРМУВАННЯ МЕТОДИКИ ВИЗНАЧЕННЯ КІЛЬКОСТІ ВЕЛИКОВАГОВИХ ПОЇЗДІВ НА ЗАЛІЗНИЧНОМУ НАПРЯМКУ
}

Актуальність. Проведена в даний час реструктуризація залізничного транспорту передбачає впровадження на мережі залізниць нової експлуатаційної моделі управління технологією перевезень, яка передбачає поліпшення показників використання рухомого складу.

Відповідно до програми розвитку Укрзалізниці на період до 2020 року в перспективі намічається зростання обсягів перевезень, що вимагатиме додаткових пропускних i провізних спроможностей залізничних ліній.

Одним з найбільш ефективних заходів 3 підвищення пропускної спроможності залізниць $\epsilon$ збільшення норм маси та довжини поїздів. Стримуючим фактором збільшення довжини вантажних поїздів $\epsilon$ 
корисна довжина приймальних колій на станціях. Для усунення цього обмеження потрібні значні витрати на реконструктивні заходи щодо збільшення ємності колій. Очевидно, що одночасно подовжити приймально-відправні колії на всіх станціях залізничного напрямку неможливо. Тому визначення доцільності перебудови кожного роздільного пункту на залізничному полігоні значної протяжності $\epsilon$ досить трудомістким завданням. Викладене свідчить про актуальність проблеми і необхідність розробки методики 3 визначення заходів на залізничному напрямку в умовах просування великовагових поїздів.

Аналіз літератури і досліджень. На підставі аналізу наукової літератури з теми дослідження та узагальнення практичного досвіду експлуатаційної роботи при веденні довгосоставних і великовагових поїздів на вітчизняних і зарубіжних залізницях можна зробити висновок, що для освоєння поїздопотоків довгосоставних i великовагових поїздів необхідно мати в наявності станційні колії достатньої корисної довжини. Як показав аналіз, більшість станцій 3 моменту їх спорудження не перебудовувалися. Довжина приймальних колій на них залишилася в межах 900 м і менше.

Великий науковий i практичний внесок у розробку питань, пов'язаних 3 подальшим підвищенням середньої маси i довжини вантажних поїздів, зростанням провізної спроможності окремих ліній для різних умов їх експлуатації зробили I.I. Васильєв, Н.А. Воробйов, Ю.В. Дьяков,

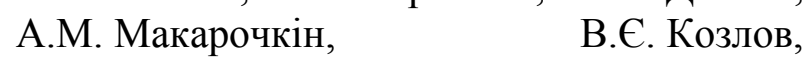
В.А. Кудрявцев, Є.В. Архангельський, В.М. Правдин, А.Д. Чернюгов, В.С. Алійник, Т.В. Бутько і багато інших.

У сучасних умовах ринкової економіки, коли необхідно підвищувати доходи, не збільшуючи собівартість послуг 3 перевезення вантажів, а також підвищувати конкурентоспроможність залізниць, є необхідність розробки низки нових методик, що дозволяють досліджувати вплив різних факторів на експлуатаційні витрати 3 пропуску довгосоставних вантажних поїздів.

Вітчизняними

залізницями накопичений великий досвід ведення довгосоставних поїздів. У практиці експлуатації пропуск довгосоставних поїздів по ділянці пов'язаний 3 певними труднощами в умовах обмеженої корисної довжини приймальних колій на проміжних станціях. Найбільші затримки виникають при прийманні на проміжні станції довгосоставних вантажних поїздів під обгін пасажирськими.

Експлуатація залізниць в Україні та їх технічна оснащеність має свої особливості, що не дозволяють повною мірою використовувати зарубіжний досвід. У нашій країні вантажонапруженість набагато вище, більшість залізничних ліній пролягають по дуже пересіченій місцевості 3 численними підйомами та спусками великої протяжності і крутизни. Крім того, у зв'язку 3 особливостями руху по пересіченій місцевості краще підходить електрична тяга. Враховуючи великі відстані прямування пасажирських поїздів, уникнути виключення їх просування вночі неможливо. Поділ вантажного i пасажирського руху спричинить дуже великі капітальні витрати.

Аналіз наукових робіт довів, що дослідженню затримок рухомого складу стосовно до реконструкції 3 подовження станційних колій практично не було приділено уваги. Одночасно виконати всі роботи 3 подовження колій на станціях ділянки неможливо, необхідно планувати етапність інвестицій 3 урахуванням наявних ресурсів.

Основним елементом аналізу структури поїздопотоків $є$ встановлення чинників, до яких належать способи організації поїзної роботи на дільницях, які полягають у визначенні комбінацій i призначень поїздів різної маси і довжини в 
окремі потоки, а також технологія пропуску їх на двоколійному напрямку [1, 2]. Від режиму роботи істотно залежить потрібне число подовжених станційних колій, локомотивів і локомотивних бригад, тобто технічна оснащеність лінії, яка необхідна для організації сталого спільного пропуску поїздів різної вагової категорії. Організація поїзної роботи на двоколійному лінійному напрямку в умовах обігу поїздів різної вагової категорії може здійснюватися за трьома варіантами:

- організація руху поїздів, як правило, масою 6000 т і більше в навантаженому напрямку і порожніх довжиною 1050 м i більше у зворотному 3 використанням станційних колій підвищеної довжини;

- організація руху з'єднаних блокпоїздів при існуючому оснащенні лінії;

- організація руху великовагових, довгосоставних i блок-поїздів при подовженні станційних колій на передвузлових i обгінних станціях до довжини, що відповідає довжині блокпоїздів.

Перший варіант широко застосовується на мережі залізниць i приносить певний ефект за рахунок скорочення числа поїздів, збільшення середньої маси і т.д. При цьому поєднання поїздів підвищеної маси в завантаженому напрямку і збільшеної довжини в порожньому напрямку збільшує непарність обміну поїздів по стикових пунктах i основних депо, внаслідок чого погіршується якість використання локомотивного парку.

Другий варіант отримав широке застосування. Він полягає в організації пропуску з'єднаних поїздів без істотних змін у технічному оснащенні ліній. При цьому проблему збільшення провізної i пропускної спроможності неможливо вирішити в повному обсязі внаслідок незабезпечення безперебійності руху поїздів, великих простоїв поїздопотоків при з'єднанні - роз'єднанні на перегонах i стоянок під обгоном або схрещеннях.
Тому основним способом підвищення пропускної і провізної спроможності дільниці $\epsilon$ система сталого обертання поїздів підвищеної маси і довжини 3 різними схемами формування (блок-поїзди, одинарні великовагові, довгосоставні та ін.) на основі відповідного технічного забезпечення, яке орієнтоване на вирішення такого комплексу завдань:

- підвищення використання локомотивів на основі формування частини блокпоїздів;

- стійке дотримання режиму роботи локомотивних бригад діленням ділянок обігу на передвузлові (вивізний принцип) i лінійні (поїзний принцип);

- збільшення середньої маси поїзда відповідно до частки вільності бригад i локомотивів.

Для організації руху одинарних поїздів підвищеної маси i довжини потрібно подовження приймальновідправних колій на основних технічних станціях дільниці. Як правило, на великих технічних станціях 3 декількома коліями великої довжини необхідно лише визначити переробну спроможність цих колій залежно від організації технічного огляду (бригадою ПТО у дві або три групи) і порівняти іiі з потрібними розмірами руху одинарних великовагових поїздів.

При розгляді варіантів пропуску поїздів підвищеної маси i довжини розглядається принцип розробки технічної основи спільного пропуску поїздів різної маси і довжини 3 найменшою перебудовою технічної бази лінії і зміною локомотивного парку, яке скоротить капітальні вкладення в технічну реконструкцію лінії.

Для дільниць 3 кількома технічними станціями можна скомбінувати значну кількість варіантів обертання блок-поїздів, число яких обмежує оснащеність технічних пристроїв. За рахунок дальності проходження блок-поїздів без розформування та зміни локомотивів число варіантів для лінійного напряму може скоротитися до двох-чотирьох. Дільниці 
обертання блок-поїздів вибираються так, щоб їх довжина була кратна вагонному плечу (пробігу між технічними оглядами вагонів), а дільниці обігу локомотивних бригад не перевищували локомотивних плечей (тобто щоб варіантна дільниця на стиках мала основне або оборотне депо). Внаслідок цього: виникнуть витрати на створення та утримання додаткових пунктів технічного огляду, ускладнюється прив'язка локомотивів і бригад до «ниток» блок-поїздів, а в окремих випадках збільшаться витрати, пов'язані 3 регулюванням локомотивного парку.

Відповідно до цього проведено дослідження пропускної спроможності дільниць напрямку Куп'янськСортувальний - Одеса-Сортувальна в умовах пропуску спеціалізованих поїздів.

Згідно 3 проведеним аналізом характеристик дільниць на напрямку до обмежуючих дільниць слід віднести одноколійні 3 двоколійними вставками: Полтава-Півд - Кременчук та Помічна Колосівка (див. таблицю).

Таблиця

Характеристика дільниць на напрямку Куп'янськ-Сорт. - Одеса-Сорт.,

Одеса-Застава-1, Берегова

\begin{tabular}{|l|c|l|}
\hline \multicolumn{1}{|c|}{ Назва дільниці } & $\begin{array}{c}\text { Довжина дільниці, } \\
\text { км }\end{array}$ & \multicolumn{1}{|c|}{$\begin{array}{c}\text { Кількість головних колій на } \\
\text { дільниці }\end{array}$} \\
\hline Куп'янськ-Сорт. - Основа & 122,46 & двоколійна \\
\hline Основа - Полтава-Півд & 139,307 & двоколійна \\
\hline Полтава-Півд - Кременчук & 117,349 & $\begin{array}{l}\text { одноколійна 3 двоколійними } \\
\text { вставками }\end{array}$ \\
\hline Кременчук - Знам'янка-Сорт. & 97,928 & $\begin{array}{l}\text { частково двоколійна, крім } \\
\text { одноколійних перегонів: } \\
\text { Кременчук - Крюків-на- } \\
\text { Дніпрі та Знам'янка-Пас. - } \\
\text { Знам'янка-Сорт. }\end{array}$ \\
\hline Знам'янка-Сорт. - Помічна & & $\begin{array}{l}\text { двоколійна, крім } \\
\text { одноколійного перегону } \\
\text { Новоукраїнка - П. 218 км }\end{array}$ \\
\hline Помічна - Колосівка & 136,062 & $\begin{array}{l}\text { одноколійна з двоколійними } \\
\text { вставками }\end{array}$ \\
\hline Колосівка - Чорноморська & & двоколійна \\
\hline Чорноморська - Берегова & 142,65 & одноколійна \\
\hline Колосівка - Одеса-Сорт. & 74,494 & двоколійна \\
\hline Одеса-Сорт. - Одеса-Застава-1 & 36,998 & одноколійна \\
\hline
\end{tabular}

Отже, дільниця напрямку 3 найменшою пропускною спроможністю визначає результативну пропускну спроможність напрямку в цілому. Приймаючи за обмежувальну одноколійну дільницю 3 двоколійними вставками, можна визначити на паралельному графіку максимально можливу кількість ниток для руху звичайних вантажних поїздів за виразом

$$
N_{\text {ван }}^{\max }=\frac{\left(1440-t_{\text {mex }}\right) \alpha_{\mu}}{T_{\text {nep }}},
$$

де $t_{\text {mеx }}$-тривалість технологічного вікна для одноколійної дільниці $з$ двоколійними вставками, $t_{\text {mex }}=120$ хв; 


$$
\alpha_{\mu} \text {-коефіцієнт надійності, який }
$$
враховує вплив відмов у роботі технічних засобів (колії, пристрої СЦБ і зв'язку, контактна мережа тощо) на наявну пропускну спроможність лінії. За умови обертання поїздів підвищеної довжини та ваги при електричній тязі можна прийняти $\alpha_{H}=0,89$;

$T_{\text {nep }}-$ період графіка, хв.

Згідно 3 проведеними тяговими розрахунками визначено, що втрата часу при проходженні по дільниці поїздів підвищеної ваги становить близько 3 \% у порівнянні 3 поїздами уніфікованої ваги (4200-4600 т). Причому, практичний досвід організації руху поїздів підвищеної ваги та довжини свідчить, що, як правило, такі поїзди прямують згідно з графіком, а часто i 3 перевищенням швидкості, що встановлена графіком руху поїздів. Отже, для розрахунків доцільно прийняти час руху спеціалізованого поїзда рівним часу руху звичайних вантажних поїздів.

Основною умовою пропуску спеціалізованого поїзда по дільницях напрямку $\epsilon$ їх пріоритетний пропуск, а за умови підвищеної довжини таких поїздів і відсутності на дільниці приймальновідправних колій для зупинки, можливим варіантом прокладання ниток ходу у вантажному напрямку (непарному) на обмежувальному перегоні є схема пропуску непарних поїздів з ходу через обмежуючий перегін (див. рисунок).

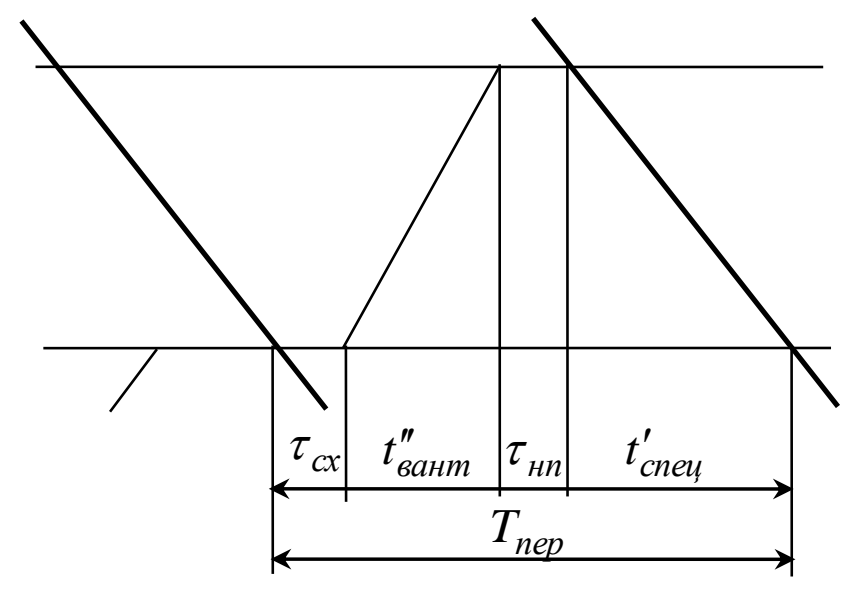

Рис. Схема прокладання поїздів на максимальному перегоні

Якщо прийняти за $N_{\text {ван }}^{\max }$-число ниток на графіку руху, що призначені для вантажного руху, а через $N_{\text {ван }}$ та $Q-$ відповідно число та вагу звичайних вантажних, що пропускаються на напрямку поряд із спеціалізованими поїздами
$\left(N_{\text {cneu }}\right)$, то загальну пропускну спроможність дільниці $N_{\text {ван }}^{3 a а ~(п а р ~ п о і ̈ з д і в) ~}$ для вантажного руху при пропуску частини поїздів як категорії спеціалізованих з вагою $Q_{\text {cneu }}$ можна записати

$$
N_{\text {ван }}^{\text {заг }}=\frac{\left(1-\alpha_{\text {cneu }}\right) \Gamma}{Q}+\frac{\alpha_{\text {cneu }} \Gamma}{Q_{\text {cneu }}}=\left(1-\alpha_{\text {cneu }}\right) N_{\text {ван }}^{\max }+\alpha_{\text {cneu }} \frac{N_{\text {ван }}^{\max } Q_{\text {cneu }}}{Q},
$$


де $\Gamma$-вантажопотік на напрямку, тис. тонн;

$\alpha_{\text {спеи }}$ - частка вагонопотоку, що освоюється спеціалізованими поїздами;

$\left(1-\alpha_{\text {спеи }}\right) N_{\text {ван }}^{\max }-$ число звичайних вантажних поїздів вагою $Q$;

$$
\alpha_{\text {cnеи }} \frac{N_{\text {ван }}^{\max } Q_{\text {cnеи }}}{Q}-\text { число спеціалізова- }
$$

них поїздів вагою $Q_{\text {cneu }}$.

Збільшення перевізної потужності напрямку при використанні спеціалізованих поїздів, у порівнянні 3 пропуском звичайних вантажних поїздів уніфікованої ваги, характеризується часткою ниток у графіку для пропуску спеціалізованих поїздів, яку можна вивести з виразу (3)

$$
\alpha_{\text {cneи }}=\frac{N_{\text {ван }}^{\max }-N_{\text {вaн }}^{3 a z}}{N_{\text {ван }}^{\max }+N_{\text {ван }}^{\max } \frac{Q_{\text {cneu }}}{Q}} .
$$

$$
\begin{aligned}
& N_{\text {спеи }}=\alpha_{\text {спеи }} N_{\text {ван }}^{\max }\left(\Delta_{\text {спеи }}-1\right)+N_{\text {ван }}^{\max }-N_{\text {ван }}^{\max }+\alpha_{\text {спеи }} N_{\text {ван }}^{\max }, \\
& \Downarrow \\
& N_{\text {cпеи }}=\alpha_{\text {спеи }} N_{\text {ван }}^{\max }\left(\Delta_{\text {сnец }}-1\right)+\alpha_{\text {сnещ }} N_{\text {ван }}^{\max } \text {, } \\
& \Downarrow \\
& N_{\text {cneu }}=\alpha_{\text {cneu }} N_{\text {ван }}^{\max } \Delta_{\text {cneu }} \text {. }
\end{aligned}
$$

Згідно 3 прийнятою схемою прокладення поїздів через обмежувальний перегін можна визначити період графіка та перевірити мінімально необхідну кількість проміжних станцій 3 подовженими приймально-відправними коліями. Розрахунок потрібної кількості проміжних роздільних пунктів з однією подовженою колією при “жорсткому” графіку руху спеціалізованих поїздів зводиться до наступного. Оскільки у русі перебувають не тільки спеціалізовані поїзди, а ще й поїзди інших категорій (збірні, прискорені, просто вантажні), то на графіку спеціалізовані та одинарні поїзди чергуються, внаслідок чого інтервал між спеціалізованими поїздами або, що теж саме, період графіка спеціалізованих поїздів $T_{\text {cnеч }}$ значно більший періоду графіка обмежуючого перегону $T_{n e p}$.

Якщо врахувати, що поїзди з вищою швидкістю займають на графіку певний час і тим самим знімають частину пропускної спроможності, тоді період графіка для пропуску спеціалізованих поїздів (за методикою І.Г. Тихомирова), хв, [3] 


$$
T_{\text {cneu }}=\frac{1440-\sum N_{n c} \varepsilon T_{n e p} j}{N_{\text {cneu }}}=\frac{1440-\sum N_{n c} \varepsilon T_{n e p} j}{\alpha_{\text {cneu }} N_{\text {ван }}^{\max } \Delta_{\text {cneu }}},
$$

де $\sum N_{n c} \varepsilon-$ кількість поїздів зі швидкістю, що відрізняється від швидкості звичайних вантажних поїздів пасажирських, прискорених, збірних та їх коефіцієнти зйому;

$T_{n e p}-$ період графіку на обмежуючому перегоні;

$j$ - коефіцієнт неідентичності перегонів на розрахунковій дільниці, що знаходиться за виразом

$$
j=\frac{\left(\sum t_{1}+\sum t_{2}+\ldots+\sum t_{n}\right) / \Pi}{\sum t_{\max }},
$$

де $\sum t_{n}-$ загальний час ходу по перегонах дільниці, хв;

$$
\sum t_{\max }-\text { значення часу ходу по }
$$
обмежуючому перегону, хв;

П -число перегонів на дільниці.

Оскільки періоди графіка перегонів дільниці будуть менше періоду $T_{\text {сnеи }}$, то такі перегони можна об'єднувати для пропуску спеціалізованих поїздів. Тоді число перегонів $\Pi_{\text {граф }}$, що можна об'єднати у загальний період, або порядковий номер станції 3 подовженою приймально-відправною колією можна знайти за

$$
\Pi_{\text {граф }}=n_{i}=\frac{T_{\text {cneu }}}{T_{\text {nep }} j}=\frac{1440-\sum N_{n c} \varepsilon T_{\text {nep }} j}{\alpha_{\text {cneu }} N_{\text {ван }}^{\max } \Delta_{\text {cneu }} T_{\text {nep }} j}
$$

Кількість схрещень спеціалізованих поїздів на їх пару або число проміжних роздільних пунктів, на яких необхідно мати одну приймально-відправну колії місткістю 65 ум.ваг. для забезпечення схрещення таких поїздів

$$
k_{c x}=n_{\text {подов }}^{\text {ван }}=\frac{(n+1)}{\Pi_{\text {граф }}}-1=\frac{(n+1) \alpha_{\text {спеи }} N_{\text {ван }}^{\max } \Delta_{\text {спец }} T_{\text {пер }} j}{1440-\sum N_{n c} \varepsilon T_{\text {nер }} j}-1,
$$

де $n-$ кількість проміжних станцій на дільниці.

Висновок. Згідно 3 визначеними обмежуючими одноколійними дільницями Полтава-Півд - Кременчук та Помічна Колосівка та запропонованою методикою проведені розрахунки необхідного числа приймально-відправних колій, що можуть мати місткість 71 ум.ваг. для безперешкодного пропуску спеціалізованих поїздів.

\section{Сиисок літератури}

1. Тихонов, К.К. Выбор весовых норм грузовых поездов [Текст] / К.К. Тихонов. - М.: Транспорт, 1967. - 260 с.

2. Тихонов, К.К. Технико-экономические расчеты в эксплуатации железных дорог [Текст] / К.К. Тихонов. - М.: Транспорт, 1962. - 252 с. 
3. Организация движения на железнодорожном транспорте [Текст] / И.Г. Тихомиров, П.А. Сыцко, П.С. Грунтов [и др.]; gод общ. ред. И.Г. Тихомирова. - 3-е изд. - Мн.: Выш. школа, 1979. - Ч.2. - 224 с.

Ключові слова: залізничний напрямок, провізна спроможність, великовагові поїзди.

\section{Анотації}

В роботі наведено удосконалену методику для розрахунку раціональної кількості великовагових поїздів для залізничного напрямку. Це дозволяє збільшити провізну спроможність залізничної лінії.

В работе приведена усовершенствованная методика для расчета рационального количества тяжеловесов для железнодорожного направления. Это позволяет увеличить провозную способность железнодорожной линии.

This paper provides an improved method for calculating the rational number of heavy trains for rail direction. This can increase the carrying capacity of railway lines. 